\title{
Mating competition between farmed and wild cod Gadus morhua
}

\author{
J. E. Skjæraasen ${ }^{1, *}$, J. J. Meager ${ }^{1}$, Ø. Karlsen ${ }^{2}$, I. Mayer $^{1,3}{ }^{,}$G. Dahle ${ }^{2}$, G. Rudolfsen ${ }^{4}$, \\ A. Fernö ${ }^{1}$ \\ ${ }^{1}$ Department of Biology, University of Bergen, 5020 Bergen, Norway \\ ${ }^{2}$ Institute of Marine Research, 5817 Bergen, Norway \\ ${ }^{3}$ Norwegian School of Veterinary Science, 0033 Oslo, Norway \\ ${ }^{4}$ Department of Evolution and Ecology, University of Tromsø, 9037 Tromsø, Norway
}

\begin{abstract}
Increasing numbers of hatchery-produced fish entering marine environments has caused concern over potential fitness depressions in wild populations, yet no study has addressed the likelihood of hybridisation between farmed and wild marine fish. Escape rates of Atlantic cod Gadus morhua L. from commercial net pens have been substantial and there is a risk of interbreeding between depleted local coastal populations and escapees. We studied mating competition between farmed and wild cod in 2 mixed spawning groups. In addition to detailed behavioural analysis, we examined a suite of individual male characteristics thought to be associated with male reproductive success, including, for the first time in any 'naturally' spawning teleost, sperm motility traits. We found that the expression of reproductive behaviours was similar for both male types (farmed and wild). Males 'courted' both sexes, but courtships lasted longer with a female recipient. Both farmed and wild males also directed most female courtships towards farmed females. The frequency of male displays was linked to their steroid levels. Wild males sired $75 \%$ of eggs spawned by wild females, but only 48 to $67 \%$ of eggs spawned by farmed females. It is likely that wild females rejected farmed males and chose among the wild males based primarily on behavioural cues. Female choice thus appears to be an integral part of the cod mating system. Sperm traits were not associated with overall reproductive success. Our results suggest that hybridisation between farmed escapees and wild cod is likely and that farmed cod may interfere with the natural spawning behaviour of cod.
\end{abstract}

KEY WORDS: Genetic introgression $\cdot$ Leks $\cdot$ Female choice $\cdot$ Sperm traits $\cdot$ Gadus morhua

\section{INTRODUCTION}

Declining wild stocks have provided the impetus for developing mariculture, culture-based fisheries and restocking (Brown \& Laland 2001, Pauly et al. 2002). This has led to a worldwide increase in the number of hatchery-produced fish entering marine environments, from both intentional releases and escapes from farms (Born et al. 2004, Naylor et al. 2005). There is a concern about the potential for these farmed fish to impact on the genetic integrity of wild populations, for example by introgression of farmed genes (e.g. Bekkevold et al. 2006). Numerous studies have addressed this issue in anadromous salmonids; generally, farmed males are inferior to their wild counterparts and females are the main vector for farmed genes into wild populations (Fleming et al. 1996, Weir et al. 2004). In contrast, we are aware of no study that has examined the outcome of mating competition between farmed and wild marine fish.

The chance of hybridisation is likely to be linked to the mating system of the species in question. In lekking species, males form localised groups that females visit to choose a mate (Höglund \& Alatalo 1996). Although no non-genetic resources are gained, the male reproductive skew is usually very high (Kirkpatrick \& Ryan 1991, Neff \& Pitcher 2008). In fish, there are comparatively few descriptions of leks. One example 
is African cichlids where males can attract females by building bowers, which females subsequently use to assess males (e.g. McKaye 1983). The batchspawning Atlantic cod Gadus morhua L. also possess a complex lek-like mating system (e.g. Brawn 1961a, Hutchings et al. 1999, Nordeide \& Folstad 2000), and are one of the few cultured marine species for which reproductive behaviour has been studied in detail. Males act aggressively towards other males, court females with acoustic and behavioural displays, and broadcast spawning occurs when a female has been ventrally mounted by a male (Brawn 1961a, Hutchings et al. 1999, Rowe \& Hutchings 2006). After gamete release by the mated pair, other males commonly rush in and release sperm (Hutchings et al. 1999), imposing sperm competition (Birkhead \& Møller 1998).

With declining wild cod populations (Hutchings \& Baum 2005), cod farming is now a rapidly developing industry in coastal areas used as spawning sites by cod in the North Atlantic (Kjesbu et al. 2006). The number of escapes from net-pens has, to date, been surprisingly high (Moe et al. 2007), and experimentally released farmed cod are known to navigate to local spawning grounds (Svåsand et al. 1990, Uglem et al. 2008) and join spawning shoals (Meager et al. 2009). In salmonids, hybridisation between escaped farmed and wild fish has resulted in genetic introgression and fitness depression in wild populations (McGinnity et al. 2003, Araki et al. 2007). The highly localised genetic population structure of coastal cod populations (e.g. Sarvas \& Fevolden 2005) and possible local adaptation (Olsen et al. 2008) suggests the potential for farmed genotypes to swamp local genetic structure leading to the breakdown of co-adapted gene complexes (Ward 2006, Darwish \& Hutchings 2009). It is therefore paramount to assess the likelihood of interbreeding between escapees and wild cod.

Farming and domestication typically affect traits associated with mate choice and reproductive success, such as morphology, physiology and reproductive behaviour (e.g. Huntingford 2004, Jonsson \& Jonsson 2006). For example, farmed male Atlantic salmon are outcompeted by wild males, due to wild behavioural dominance and failure of farmed males to release sperm concurrently with female egg release (Fleming et al. 1996, Weir et al. 2004). In captive groups of wild cod, male reproductive success is positively associated with body size and reproductive behaviour (Rowe et al. 2008). Thus, examining the reproductive success of farmed cod in mating competition with wild cod will not only indicate the risk of genetic introgression, but illuminate further the link between male morphology, behaviour and reproductive success in a lekking marine broadcast spawner.
We therefore studied mating interactions between farmed and wild cod in mixed groups. To determine the causal mechanism for the observed patterns of reproductive success, we examined a suite of behavioural, physiological and morphological traits, including, for the first time in any 'naturally' spawning teleost, sperm motility.

\section{MATERIALS AND METHODS}

History of fish. All experimental cod originated from local coastal cod caught in the vicinity of Bergen, Norway. Wild coastal cod were caught by hook and line, and fish traps (6 to $20 \mathrm{~m}$ depth) in the Herdla-Øygarden area: 51 fish were caught at $60^{\circ} 29^{\prime} \mathrm{N}, 4^{\circ} 53^{\prime} \mathrm{E}$, and 24 fish were caught at $60^{\circ} 34^{\prime} \mathrm{N}, 4^{\circ} 56^{\prime} \mathrm{E}$ between November and January 2006. Fish were kept at the site of capture until transfer to the Institute of Marine Research (IMR) facility at Austevoll $\left(60^{\circ} 05^{\prime} \mathrm{N}, 5^{\circ} 15^{\prime} \mathrm{E}\right)$ in late January, where the fish were placed in a $28 \mathrm{~m}^{3}$ holding tank. Wild cod were fed a mixture of shrimp and fish prior to the experiment.

Farmed F1-generation cod were obtained from a population maintained under commercial conditions typical for farming at IMR. These cod were the progeny of local wild cod again caught at Øygarden $\left(60^{\circ} 37^{\prime} \mathrm{N}, 4^{\circ} 48^{\prime} \mathrm{E}\right)$ and hatched in spring 2003 and 2004. Further details on the pre-experimental protocol are given in Skjæraasen et al. (2008).

Experimental fish. Cod were selected for the experiment on February 20 and 22. Fish were first sedated with metacaine $\left(0.5 \mathrm{~g} \mathrm{l}^{-1}\right)$ and then examined with ultrasound to determine the sex of each fish (Karlsen \& Holm 1994). All experimental males released milt following the application of gentle pressure on their ventral side. Milt samples were collected into $50 \mathrm{ml}$ vials for subsequent analyses of male sperm traits. Similarly, all experimental females were either running with eggs, or based on the ultrasound image, thought to be close to ovulation. Fish were then measured for total length $( \pm 1 \mathrm{~cm})$ and whole body weight $( \pm 1 \mathrm{~g})$. In addition, vernier calipers were used to measure pelvic fin length, a secondary sexual characteristic (Skjæraasen et al. 2006), from the base of the pelvic fin to the tip of the longest pelvic fin ray $( \pm 0.1 \mathrm{~cm})$. A blood sample was withdrawn from the caudal vein for subsequent measurement of sex steroid levels. All fish were then individually tagged with 2 white, $7 \mathrm{~cm}$ Floy T-bar tags following the procedure of Hutchings et al. (1999) and distributed between 2 mating arenas at equal ratios of males to females, and wild to farmed cod. We kept $40 \mathrm{cod}$ in Tank 1 ( $7 \mathrm{~m}$ diameter, $1.4 \mathrm{~m}$ depth, volume $\left.53.9 \mathrm{~m}^{3}\right)$ and 24 cod in Tank $2(5 \mathrm{~m}$ diameter, $1.4 \mathrm{~m}$ depth, volume $27.5 \mathrm{~m}^{3}$ ). An egg collector skimmed 
eggs from the surface waters of each tank. Fish were allowed 1 to $2 \mathrm{~d}$ to recover after sampling before the behavioural observations commenced on February 23.

All fish were euthanised by an overdose of anaesthetic on March 26. Drumming muscles (Brawn 1961b) were then removed using forceps and dried at $60^{\circ} \mathrm{C}$ for $3 \mathrm{~d}$ to obtain dry weight to the nearest $0.0001 \mathrm{~g}$. Otoliths were also removed from all wild fish for age determinations. During the course of the experiment, 3 farmed and 2 wild females died in Tank 2 on March 8, 16, 27, 12 and 19, respectively, whereas 1 farmed female died in Tank 1 on March 25 and, unfortunately, was disposed of before a tissue sample was obtained. Only 39 fish were therefore fingerprinted in Tank 1.

Hormonal analyses. Plasma concentrations of the main sex steroids for cod (e.g. Dahle et al. 2003): testosterone ( $T$, both sexes), 11-ketotestosterone (11-KT, males) and $17 \beta$-oestradiol (E2, females), were measured by radioimmunoassay following the procedure of Schulz (1985). In brief, steroids were extracted from $200 \mu \mathrm{l}$ plasma with $4 \mathrm{ml}$ diethylether. The aqueous phase was frozen on dry ice, after which the organic phase was transferred to a glass tube, evaporated in a water bath, and reconstituted with $600 \mu$ l assay buffer. Samples were assayed in duplicate.

Sperm analyses. Sperm motility was analysed following the procedure of Rudolfsen et al. (2005). The parameters included in the present study were seawater measurements of: mean average path velocity $\left(\mathrm{VAP}, \mu \mathrm{m} \mathrm{s}^{-1}\right.$ ), mean straight line velocity (VSL, $\mu \mathrm{m} \mathrm{s}^{-1}$ ), mean curvilinear velocity (VCL, $\mathrm{Mm} \mathrm{s}^{-1}$ ), percentage of motile cells (MOT) and percentage of progressive sperm (PPC, the percentage of all sperm that moved with straightness (STR) $>80$ and VAP $>25 \mu \mathrm{m} \mathrm{s}^{-1}$; $\mathrm{STR}=$ VSL/VAP). We also determined the spermatocrit values of each male, as this correlates to sperm concentration in cod milt (Rakitin et al. 1999). To achieve this, milt was collected in duplicate $75 \mathrm{~mm}$ capillary tubes. Tubes were sealed with Sigillum wax and spun for $2 \mathrm{~min}$ in a haematocrit centrifuge. The spermatocrit value was then determined as the percentage volume sperm cells in relation to total milt volume. Further details are given in Skjæraasen et al. (2009).

Behavioural observations. Both tanks were filmed using overhead CCTV cameras (Panasonic WV BP550), but the large size of Tank 1 prevented us from identifying all 40 fish simultaneously in the entire tank. In Tank 2 we had very good coverage of all 24 fish simultaneously. In this tank, we therefore recorded daily between 10:30 and 18:30 h for $31 \mathrm{~d}$ (February 23 to March 25) and subsequently analysed $15 \mathrm{~min}$ of every recorded hour in detail by scoring the frequency of reproductive behaviours (Table 1) and the identity of fish involved. Initially, we only recorded on an analogue VHS recorder, whereas from February 4 the signal from the camera in Tank 2 was split and recorded onto both a digital DV recorder and the analogue VCR. For time periods recorded on digital tape, we also recorded behaviour duration.

Egg collection and preservation of larvae. The egg collectors were emptied around 10:00 h daily and eggs were put into measuring columns and allowed $20 \mathrm{~min}$ to settle into a floating and sinking fraction. The volume of each fraction was then noted and a subsample of 100 eggs from each fraction was examined under a microscope to back-calculate approximate spawning times based on cell stages (e.g. Kjesbu 1989) and the total ratio of fertilised eggs. In both tanks, $~ 80 \%$ of the eggs had been fertilised within the previous $24 \mathrm{~h}$ (i.e. $<256$ cells), with the remaining being no more than $48 \mathrm{~h}$ old (i.e. 256 cells).

Table 1. Gadus morhua. Behaviours scored in the present study

\begin{tabular}{|c|c|c|}
\hline Behaviour & Source & Operational definition in present study \\
\hline \multicolumn{3}{|l|}{ Courtship } \\
\hline Ventral mount & Brawn (1961a) & $\begin{array}{l}\text { A cod slides down the side of another cod, ending up stomach to stomach } \\
\text { with genital pores close together }\end{array}$ \\
\hline Paired swim & Brawn (1961a) & $\begin{array}{l}\text { The cod are }<1 \text { body length apart and the movement involves } \leq 2 \text { alterations } \\
\text { of direction (circles) and/or ends in attempted ventral mount }\end{array}$ \\
\hline Circling & Hutchings et al. (1999) & A cod rests on the bottom, while another cod swims in circles above \\
\hline Lateral display & Nilsson (2004) & $\begin{array}{l}\text { A cod approaches another cod and freezes in mid-water, flexing its pectoral } \\
\text { and pelvic fins. The behaviour lasts a minimum of } 2 \mathrm{~s} \text {, and the focal cod is } \\
<1 \text { body length away from the target cod }\end{array}$ \\
\hline \multicolumn{3}{|l|}{ Aggression } \\
\hline Approach & Hutchings et al. (1999) & $\begin{array}{l}\text { A cod approaches another cod at a speed of }>2 \text { body lengths } \mathrm{s}^{-1} \text {, ending up } \\
>1 \text { body length away from the target }\end{array}$ \\
\hline Chase & Brawn (1961a) & $\begin{array}{l}\text { A cod approaches another cod at a speed of }>2 \text { body lengths } \mathrm{s}^{-1} \text {, ending up } \\
<1 \text { body length away from the target }\end{array}$ \\
\hline Prod & Hutchings et al. (1999) & A cod swims into the side of another cod, making contact with its snout \\
\hline Nip/bite & Hutchings et al. (1999) & A cod bites or attempts to bite another cod \\
\hline
\end{tabular}


Every day, 300 live eggs were taken from the floating fraction and pipetted into two $0.4 \mathrm{l}$ seawater filled containers. These containers were left overnight in a constant-temperature cabinet maintained at $10^{\circ} \mathrm{C}$, and then floating eggs were siphoned out and put in a new container until hatching. Dead eggs were siphoned out daily and water exchanged every third day to avoid bacterial growth. After hatching, larvae $<24 \mathrm{~h}$ post-hatch were preserved in ethanol for later pedigree analyses.

Parentage analyses. DNA was extracted from whole larvae. We added a mixture of $3 \mu \mathrm{l}$ of Proteinase K $\left(20 \mathrm{mg} \mathrm{ml}^{-1}\right)$ and $100 \mu \mathrm{l}$ of a $10 \%$ Chelex solution (Tris, $50 \mathrm{mM}$ EDTA, $2 \% \mathrm{SDS}$ ) to each larva and left the mixture overnight at $55^{\circ} \mathrm{C}$. The proteinase was then inactivated by putting the mixture at $95^{\circ} \mathrm{C}$ for $15 \mathrm{~min}$. The number of genotyped offspring from each day averaged $36.1 \pm 12.5$ (SD) (range: 10 to 93 ) across tanks. All parents were first genotyped twice with available microsatellites to ensure correct genotyping (error rate $0.79 \%$ ). Then, a set of microsatellites was chosen based on a predictive analysis in FAP 3.6 (Family Assignment Program) (Taggart 2007). In Tank 2, larvae were analysed with 8 microsatellites: Gmo2, Gmo3, Gmo8, Gmo19, Gmo35, Gmo37, Gmo132 and Tch11 (Brooker et al. 1994, Miller et al. 2000, O'Reilly et al. 2000). Two additional microsatellites (Gmo16 and Gmo18; Wesmajervi et al. 2007) were used in Tank 1 because of the larger number of possible parental combinations (380) compared to Tank 2 (144). All loci were amplified in 3 (Tank 2) or 4 (Tank 1) multiplexes, run on an ABI3730 sequencer, and alleles were determined with the Genemapper program (Applied Biosystems). Due to the nature of PCR amplifications, i.e. occasionally no fragments produced, $\sim 7 \%$ of the offspring could not be assigned to a specific family in either tank. The putative parental genotypes were simulated with FAP 3.6 to predict the resolving power of the specific parental data set for unambiguous discriminating among families. For Tank 1 the predicted assignment was $81.2 \%$, with no significant difference between the possible family combinations (308), and for Tank 2 the predicted assignment was $100 \%$. Thus, there was no indication that the probability of identifying both parents depended on the dyadic combination, i.e. Fơ Wo (farmed female, wild male), Fo $\mathrm{F}_{\mathrm{q}}$, etc., in either tank. In total, $71.3 \%\left(\mathrm{n}_{\text {identified }}=1040\right)$ and $93.0 \%\left(\mathrm{n}_{\text {identified }}=\right.$ 910) of the genotyped larvae could be identified to both parents in Tanks 1 and 2, respectively. The nonfingerprinted fish in Tank 1 would thus have very little, if any, effect on the number of offspring identified to both parents. Offspring for which the pedigree could not be unambiguously established were excluded from further analyses.

Data analyses. Behavioural displays of farmed and wild cod: We explored potential differences in repro- ductive behaviour between fish types from the detailed individual observations obtained in Tank 2 . We first examined if there was a difference between farmed and wild males in (1) the ratio of aggressive to courtship behaviours and (2) the proportion of aggressive displays towards males of the other type, i.e. we sought to discover if there was a difference between which fish type wild and farmed males directed their aggressive displays towards and if this ratio differed from a random distribution. We also examined if the ratio of ventral mounts and paired swims directed towards females differed between male types - both Brawn (1961a) and Rowe \& Hutchings (2006) found that males 'court' both males and females - and if the observed ratio was different from a random distribution of displays towards males and females. We compared the proportion of experimental days farmed and wild females received courtships with a $t$-test. All ratios were converted to proportions and then normalised by an arcsine transformation before conducting the analyses. Each data point was weighted by the total number of individual displays relevant to each test.

We then examined if there was a difference in the duration of paired swims and ventral mounts (Table 1) between farmed and wild males and whether this depended on recipient sex. For paired swims this was done with a linear mixed-effects model (LME, nlme library of R v. 2.9.2; R Development Core Team), where the duration of paired swims was the dependent variable, and initiator type and recipient sex plus their interaction were modelled as categorical variables. Repeated measures for the initiator were treated as a random effect. As we had scored fewer durations for ventral mounts, we only included the main effects for this analysis. For both models, we used a hierarchical approach and log-likelihood ratios to arrive at the most parsimonious model.

Finally, we examined if male steroid levels were correlated to initiated displays, using linear regressions where the initial models allowed farmed and wild males to have different intercepts and slope values. All values were log-transformed and simplified as described in the previous paragraph.

Reproductive success: We tested if there was a difference in reproductive success between wild and farmed males and whether this depended on female type. We first calculated the total volume of fertilised eggs for a given day in each tank. From the DNA fingerprinting analyses we then calculated the fraction of eggs sired by a given male-female combination. This fraction was then multiplied by the volume of fertilised eggs for the day in question and then summed for individual males and females for the entire experimental period. We assumed that all fertilised eggs had a similar probability of hatching. We then used a LME model 
where the response variable was the volume of eggs sired by a given male with (1) wild and (2) farmed females. Male and female type and their interaction were treated as fixed effects. A nested random-blocks effect accounted for variation associated with differences between individual males in each tank and between tanks.

Correlates of reproductive success: We examined if male behavioural (Tank 2 only), physiological, morphological and sperm traits were correlated to male reproductive success. The response variable was the arcsine-transformed proportion of eggs sired by individual males. The independent variable was either male weight, length, residual condition (i.e. the residuals from a ln-transformed regression of male length against body mass), steroid levels, residual pelvic fin length (i.e. the residuals from a ln-transformed regression of male length against pelvic fin length), and residual drumming muscle mass (i.e. the residuals from a ln-transformed regression of body mass against drumming muscle mass). Initially female type, i.e. farmed or wild, was allowed to affect both the intercept and slope of the LME regression. Repeated measures for individual males were treated as a random effect. Analyses were performed separately for farmed and wild males in each tank. Log-likelihood ratios were used to arrive at the final model.

\section{RESULTS}

Fish sizes were matched as closely as possible (Tables 2 \& 3). In Tank 1, weight did not significantly differ between farmed or wild fish for either males or females (Student's $t$-test: $\mathrm{df}=18$, all p-values $>0.13$ ) (Tables $2 \& 3$ ). However, female wild cod were longer than female farmed cod $(t=-4.24, \mathrm{df}=18, \mathrm{p}<0.001)$ (Table 2) and wild males were slightly, but significantly,

Table 2. Gadus morhua. Female cod data. 1FW1 denotes Tank 1, wild female 1; 2FF1 denotes Tank 2, farmed female 1; etc. T: testosterone concentration; E2: 17 $\beta$-oestradiol concentration; Drum dry: drumming muscle dry weight; Court rec.: no of courtships received; Volume spawned: the calculated volume spawned that led to hatchlings (i.e. the ratio of fingerprinted larvae from an individual female for a given sampling day multiplied by the volume of fertilised eggs for the day in question and then summed up for the total experimental period). Data on pelvic fin length and drumming muscle mass have previously been used in Skjæraasen et al. (2008). -: data not determined or missing

\begin{tabular}{|c|c|c|c|c|c|c|c|c|c|}
\hline Fish & $\begin{array}{l}\text { Total length } \\
\text { (cm) }\end{array}$ & $\begin{array}{l}\text { Pelvic fin } \\
\text { length }(\mathrm{cm})\end{array}$ & $\begin{array}{c}\text { Total weight } \\
\text { (g) }\end{array}$ & $\begin{array}{c}\mathrm{T} \\
\left(\mathrm{ng} \mathrm{ml}^{-1}\right)\end{array}$ & $\begin{array}{c}\mathrm{E} 2 \\
\left(\mathrm{ng} \mathrm{ml}^{-1}\right)\end{array}$ & $\begin{array}{l}\text { Age } \\
\text { (yr) }\end{array}$ & $\begin{array}{l}\text { Drum dry } \\
(\mathrm{g})\end{array}$ & $\begin{array}{l}\text { Court rec. } \\
\text { (n) }\end{array}$ & $\begin{array}{c}\text { Volume } \\
\text { spawned (ml) }\end{array}$ \\
\hline 1FW1 & 62 & 6.7 & 3072 & 1.3 & 1.7 & 4 & 0.2808 & - & 2108 \\
\hline 1FW2 & 63 & 7.2 & 2144 & 2.1 & 1.6 & 5 & 0.1451 & _ & 466 \\
\hline 1FW3 & 60 & 6.0 & 2143 & 1.6 & 2.3 & 3 & 0.1802 & - & 1933 \\
\hline 1FW4 & 61 & 6.9 & 1936 & 1.9 & 2.7 & 4 & 0.0971 & - & 687 \\
\hline 1FW5 & 58 & 6.0 & 2320 & 2.8 & 5.9 & 4 & 0.1065 & - & 3222 \\
\hline 1FW6 & 57 & 5.6 & 1923 & 2.5 & 5.3 & 4 & 0.1366 & - & 2056 \\
\hline 1FW7 & 55 & 6.2 & 1956 & 2.1 & 7.5 & 3 & 0.2437 & - & 1686 \\
\hline 1FW8 & 65 & 6.9 & 2476 & 1.8 & 3.3 & 4 & 0.2352 & - & 2455 \\
\hline 1FW9 & 61 & 6.6 & 2132 & 3.7 & 3.8 & 4 & 0.1589 & & 4810 \\
\hline 1FW10 & 65 & 6.5 & 3204 & 1.5 & 3.2 & 4 & 0.2144 & - & 3964 \\
\hline 1FF1 & 53 & 5.1 & 2478 & 2.1 & 7.7 & 2 & 0.028 & - & 461 \\
\hline 1FF2 & 58 & 5.5 & 2920 & 1.8 & 9.2 & 2 & 0.169 & - & 302 \\
\hline 1FF3 & 56 & 4.6 & 2542 & 2.3 & 5.7 & 2 & 0.0171 & - & 870 \\
\hline 1FF4 & 52 & 5.1 & 2322 & 2.2 & 8.6 & 2 & 0.0812 & - & 896 \\
\hline 1FF5 & 56 & 5.6 & 2846 & 1.9 & 11.1 & 2 & - & - & - \\
\hline 1FF6 & 54 & 5.5 & 2520 & 1.5 & 7.7 & 2 & 0.0474 & - & 1181 \\
\hline 1FF7 & 57 & 5.2 & 2933 & 1.7 & 10.5 & 2 & 0.0198 & - & 2532 \\
\hline 1FF8 & 59 & 6.2 & 3846 & 2.2 & 7.3 & 2 & 0.2028 & - & 48 \\
\hline 1FF9 & 55 & 5.3 & 2356 & 2.3 & 7.9 & 2 & 0.0484 & - & 357 \\
\hline $1 \mathrm{FF} 10$ & 52 & 4.1 & 1976 & 1.6 & 9.9 & 2 & 0.0503 & - & 516 \\
\hline 2FW1 & 66 & 7.0 & 3158 & 1.5 & 4.2 & 4 & 0.2458 & 2 & 613 \\
\hline 2FW2 & 63 & 6.3 & 2640 & 1.1 & 5.6 & 4 & 0.1342 & 6 & 2942 \\
\hline 2FW3 & 64 & 6.3 & 2890 & 1.3 & 4.8 & 4 & 0.304 & 17 & 1995 \\
\hline 2FW4 & 65 & 7.6 & 2976 & 1.5 & 6.9 & 5 & - & 18 & 775 \\
\hline 2FW5 & 67 & 6.2 & 3198 & 1.3 & 4.8 & 4 & 0.1496 & 12 & 232 \\
\hline 2FW6 & 63 & 6.7 & 2938 & 1.2 & 3.5 & 4 & 0.224 & 9 & 4210 \\
\hline 2FF1 & 67 & 6.2 & 4262 & 1.2 & 4.1 & 3 & 0.2518 & 14 & 1687 \\
\hline $2 \mathrm{FF} 2$ & 65 & 5.3 & 3528 & 1.5 & 5.7 & 3 & 0.2329 & 36 & 111 \\
\hline 2FF3 & 66 & 7.2 & 4114 & 1 & 3 & 3 & 0.0786 & 37 & 1195 \\
\hline 2FF4 & 66 & 5.9 & 3938 & 1.2 & 3.9 & 3 & - & 72 & 765 \\
\hline 2FF5 & 64 & 5.7 & 3970 & 1.7 & 10.1 & 3 & 0.124 & 51 & 1048 \\
\hline 2FF6 & 63 & 5.4 & 3152 & 1.3 & 1.6 & 3 & 0.2102 & 51 & 914 \\
\hline
\end{tabular}


Table 3. Gadus morhua. Male cod data. 1MF1 denotes Tank 1, farmed male 1; 2MW1 denotes Tank 2, wild male 1; etc. T: testosterone concentration; 11-KT: 11-ketotestosterone concentration; VCL: curvilinear velocity; MOT: percentage of motile cells; PPC: percentage of progressive cells; Scrit: spermatocrit (sperm density); Sp exp: spawning experience; Rec: recruit spawner; Rep: repeat spawner; Drum dry: drumming muscle dry weight; A Ini.: no. of aggressions initiated; FC Ini.: no. of courtships directed at females; MC Ini.: no. of courtships directed at males; Volume sired: egg volume sired (i.e. the ratio of fingerprinted larvae sired by an individual male for a given sampling day multiplied by the volume of fertilised eggs for the day in question and then summed up for the total experimental period). Data on pelvic fin length and drumming muscle mass have also been used in Skjæraasen et al. $(2008,2009)$. -: data not determined or missing

\begin{tabular}{|c|c|c|c|c|c|c|c|c|c|c|c|c|c|c|c|c|}
\hline Fish & $\begin{array}{l}\text { Total } \\
\text { length } \\
\text { (cm) }\end{array}$ & $\begin{array}{l}\text { Pelvic } \\
\text { fin length } \\
\text { (cm) }\end{array}$ & $\begin{array}{c}\text { Total } \\
\text { weight } \\
\text { (g) }\end{array}$ & $\begin{array}{c}\mathrm{T} \\
\left(\mathrm{ng} \mathrm{ml}^{-1}\right)\end{array}$ & $\begin{array}{c}11-\mathrm{KT} \\
\left(\mathrm{ng} \mathrm{ml}^{-1}\right)\end{array}$ & $\begin{array}{c}\mathrm{VCL} \\
\left(\mu \mathrm{m} \mathrm{s}^{-1}\right)\end{array}$ & $\begin{array}{c}\text { MOT } \\
(\%)\end{array}$ & $\begin{array}{r}\text { PPC } \\
(\%)\end{array}$ & $\begin{array}{l}\text { Scrit } \\
(\%)\end{array}$ & $\begin{array}{l}\text { Age } \\
(\mathrm{yr})\end{array}$ & $\begin{array}{l}\text { Sp } \\
\exp \end{array}$ & $\begin{array}{c}\text { Drum } \\
\text { dry } \\
\text { (g) }\end{array}$ & $\begin{array}{l}\text { A } \\
\text { Ini. } \\
\text { (n) }\end{array}$ & $\begin{array}{l}\mathrm{FC} \\
\text { Ini. } \\
\text { (n) }\end{array}$ & $\begin{array}{l}\text { MC } \\
\text { Ini. } \\
\text { (n) }\end{array}$ & $\begin{array}{c}\text { Volume } \\
\text { sired } \\
(\mathrm{ml})\end{array}$ \\
\hline 1MF1 & 55.5 & 5.6 & 2158 & 7.8 & 14 & 111.8 & 71.5 & 63 & 22.5 & 2 & $\operatorname{Rec}$ & 0.2566 & - & - & - & 1584 \\
\hline $1 \mathrm{MF} 2$ & 54 & 5.9 & 2090 & 4 & 8.5 & 98.4 & 82.5 & 67.5 & 18.4 & 2 & $\mathrm{Rec}$ & 0.4475 & - & _- & - & 1030 \\
\hline $1 \mathrm{MF} 3$ & 53 & 5.9 & 2042 & 7.3 & 17.2 & 95.4 & 54.5 & 43.5 & 10.1 & 2 & $\mathrm{Rec}$ & 0.2274 & - & _- & - & 1773 \\
\hline $1 \mathrm{MF} 4$ & 52 & 5.4 & 1901 & 5.4 & 5.9 & 99.9 & 79 & 61 & 41.4 & 2 & $\operatorname{Rec}$ & 0.1767 & - & - & - & 803 \\
\hline 1MF5 & 56 & 5.4 & 2262 & 4.1 & 13.4 & 104.4 & 83.5 & 61 & 12.7 & 2 & $\operatorname{Rec}$ & 0.043 & - & - & - & 789 \\
\hline 1MF6 & 55 & 5.6 & 2118 & 4.8 & 6.1 & 75.5 & 56 & 44.5 & 18.0 & 2 & $\operatorname{Rec}$ & 0.2289 & - & - & - & 699 \\
\hline $1 \mathrm{MF7}$ & 55 & 5.8 & 1733 & 3.8 & 8.6 & 94.9 & 52 & 47 & 4.8 & 2 & Rec & 0.2102 & - & - & - & 136 \\
\hline 1MF8 & 54 & 5.8 & 1914 & 4.7 & 6 & 100.8 & 57.5 & 49 & 15.0 & 2 & Rec & 0.1284 & - & - & - & 1202 \\
\hline 1MF9 & 54 & 5.9 & 2047 & 3.3 & 4.1 & 66.6 & 16.5 & 14.5 & 15.0 & 2 & $\operatorname{Rec}$ & 0.3371 & - & - & - & 369 \\
\hline 1MF10 & 52 & 5.1 & 2074 & 7 & 8.7 & 84.5 & 44.5 & 41.5 & 11.3 & 2 & $\mathrm{Rec}$ & 0.2251 & - & - & - & 947 \\
\hline 1MW1 & 54 & 5.3 & 1665 & 3.3 & 8 & 104.7 & 64 & 56 & 11.8 & 3 & Rec & 0.2508 & - & - & - & 3789 \\
\hline 1MW2 & 51 & 6.4 & 1682 & 3.7 & 6.5 & 104.6 & 88 & 80 & 7.9 & 4 & $\operatorname{Rep}$ & 0.1311 & - & - & - & 1671 \\
\hline 1MW3 & 54 & 6.6 & 1592 & 3.5 & 7.6 & 115.65 & 91 & 69 & 28.9 & 4 & Rep & 0.2728 & - & - & - & 1074 \\
\hline 1MW4 & 61 & 7.2 & 2256 & 6.8 & 19.4 & 105.6 & 72 & 65 & 30.0 & 4 & Rep & 0.2195 & - & - & - & 887 \\
\hline 1MW5 & 58 & 6.7 & 2210 & 11.6 & 34.2 & 101.5 & 88 & 73.5 & 20.8 & 4 & Rep & 0.2712 & - & - & - & 3132 \\
\hline 1MW6 & 60 & 6.6 & 2108 & 4.8 & 10.5 & 107 & 92 & 78 & 26.4 & 4 & $\operatorname{Rec}$ & 0.3443 & - & - & - & 3780 \\
\hline 1MW7 & 59 & 7.0 & 2034 & 8.6 & 22.9 & 103.3 & 78.5 & 68 & 40.2 & 4 & Rep & 0.2531 & - & - & - & 1488 \\
\hline 1MW8 & 55 & 5.5 & 1676 & 5.7 & 17.5 & 103.3 & 89.5 & 81 & 24.8 & 5 & Rec & 0.2804 & - & - & - & 2414 \\
\hline 1MW9 & 60 & 6.4 & 2280 & 10.8 & 25 & 112.6 & 95.5 & 74.5 & 43.5 & 4 & Rec & 0.6577 & - & - & - & 1003 \\
\hline 1MW10 & 63 & 7.8 & 2374 & 3.4 & 5.2 & 106.3 & 95 & 80 & 11.9 & 4 & Rec & 0.4458 & - & - & - & 523 \\
\hline 2MW1 & 68 & 7.6 & 3418 & 1.7 & 3.2 & 102.7 & 92.5 & 69.5 & 87.8 & 4 & $\operatorname{Rec}$ & 0.7521 & 11 & 4 & 26 & 825 \\
\hline 2MW2 & 64 & 7.6 & 2798 & 6.3 & 13.2 & 80.6 & 85.5 & 73.5 & 89.2 & 3 & Rec & 0.526 & 2 & 33 & 64 & 2511 \\
\hline 2MW3 & 62 & 6.0 & 2650 & 4 & 9.9 & 121.3 & 96 & 75.5 & 25.6 & 3 & Rec & 0.3765 & 1 & 29 & 28 & 904 \\
\hline 2MW4 & 66 & 7.1 & 3400 & 4.9 & 10.1 & 130.4 & 93.5 & 64.5 & 61.4 & 4 & Rep & 0.4521 & 17 & 12 & 53 & 2331 \\
\hline 2MW5 & 63 & 7.6 & 2604 & 3.5 & 5.4 & 87.5 & 84 & 73.5 & 21.8 & 5 & Rep & 0.5015 & 2 & 14 & 11 & 2130 \\
\hline 2MW6 & 66 & 8.1 & 2826 & 3.3 & 7.5 & 112.7 & 93 & 75.5 & 52.0 & 4 & Rec & 0.6915 & 1 & 81 & 24 & 3232 \\
\hline 2MF1 & 62 & 6.1 & 3170 & 7.3 & 12.2 & 102.9 & 93.5 & 75.5 & 3.8 & 3 & Rep & 0.5903 & 9 & 28 & 68 & 160 \\
\hline 2MF2 & 65 & 6.3 & 3170 & 3.1 & 4 & 92.2 & 93.5 & 84.5 & 42.5 & 3 & Rep & 0.5114 & 33 & 18 & 10 & 1332 \\
\hline 2MF3 & 63 & 5.7 & 3208 & 6.4 & 13.5 & 70 & 60 & 45.5 & 11.7 & 3 & Rep & 0.7662 & 110 & 77 & 246 & 1122 \\
\hline 2MF4 & 67 & 6.4 & 3466 & 4.1 & 6.8 & 116 & 98 & 69.5 & 41.7 & 3 & Rep & 0.7231 & 3 & 12 & 18 & 447 \\
\hline 2MF5 & 59 & 5.9 & 2630 & 5.2 & 6.3 & 104.3 & 95 & 77.5 & 21.7 & 3 & Rep & 0.5545 & 78 & 41 & 43 & 650 \\
\hline 2MF6 & 67 & 6.1 & 3402 & 4.3 & 5.1 & 103.9 & 85.5 & 71.5 & 26.8 & 3 & Rep & 1.0885 & 1 & 28 & 53 & 843 \\
\hline
\end{tabular}

longer than farmed males $(t=-2.65, \mathrm{df}=18, \mathrm{p}=0.016)$ (Table 3). In Tank 2, neither males nor females differed significantly in length ( $\mathrm{df}=10, \mathrm{p}>0.54)$ (Tables $2 \& 3$ ). Males were of similar weight $(t=0.27, \mathrm{df}=10, \mathrm{p}=0.27$ ) (Table 3), but farmed females were significantly heavier than wild females $(t=4.60, \mathrm{df}=10, \mathrm{p}=0.001)$ (Table 2$)$. Farmed cod had significantly higher condition than wild cod in both tanks ( $t$-tests on Fulton's $K$, all p-values < 0.001). Macroscopic gonad examination revealed that all cod were nearly spent or well into their spawning period at sacrifice. In Tank 1, farmed females had higher plasma levels of E2 than wild females $(t=6.031$, $\mathrm{df}=18$, $\mathrm{p}<0.001$ ) (Table 2). All other hormonal levels were similar between farmed and wild fish of either sex in both tanks (all p-values > 0.14) (Tables $2 \& 3$ ).

\section{Reproductive behaviour of farmed and wild cod}

There was no difference in the total amount of displays initiated by farmed or wild males $(t=1.26$, $\mathrm{df}=$ 10, $\mathrm{p}=0.24$ ) (Table 3). We found no difference between farmed and wild males in any of the variables tested, i.e. the ratio of aggressions to courtships, to which type of males aggression was directed, the proportion of ventral mounts and paired swims directed at females compared to males, and to which type of female males directed their courtships (all p-values > 0.063). Interestingly, the proportion of paired swims and ventral mounts directed at females was less than expected based on a random distribution ( $t$-tests, Tank 2: both p-values < 0.01) (Fig. 1A). Males also 

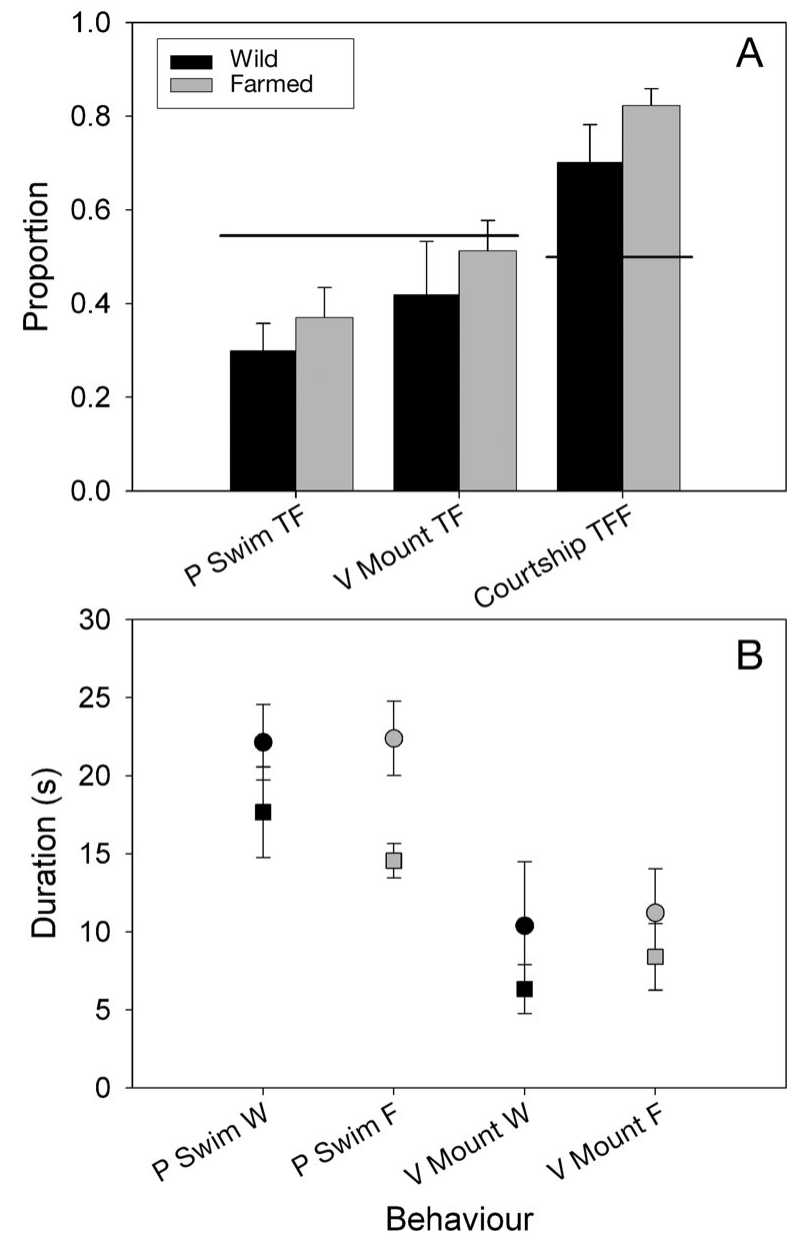

Fig. 1. Gadus morhua. Behavioural patterns of farmed (grey) and wild (black) males in Tank 2. (A) Proportion of the total number of observations for the behaviour in question. $\mathrm{P}$ Swim: paired swim, V Mount: ventral mount, TF: towards females, TFF: towards farmed females. Horizontal line above or through bars depicts the expected value for the behaviour in question if it was distributed randomly against the potential target fish. (B) Duration of paired swims and ventral mounts initiated by wild (W) and farmed (F) males towards female $(\bullet, \bigcirc)$ and male $(\square, \square)$ recipients. Error bars $=$ SE in average duration between different males

directed significantly more courtships towards farmed females ( $t$-test, Tank 2: $t=6.82$, df $=11, \mathrm{p}<0.001$ ) (Fig. 1A) and courted these females on proportionally more days than wild females (Tank 2: average proportion 0.62 vs. 0.27 ; $t$-test: $\mathrm{df}=10, t=2.94, \mathrm{p}<0.05$ ) (data not shown). Males initiated $99 \%$ of all aggressions ( $\mathrm{n}=$ $302)$, and where both fish could be identified $(\mathrm{n}=260)$ the recipient was male in $99.6 \%$ of the cases.

Paired swims lasted longer when the recipient was a female than a male (LME model: $\mathrm{df}=295, t=-2.47, \mathrm{p}<$ 0.05; $\mathrm{n}=308$ ) (Fig. 1B), which was the only significant explanatory variable of paired swim duration. A similar non-significant tendency was observed for the fewer recordings of ventral mounts $(n=112)$. Male steroid values around the onset of spawning tended to be positively associated with the number of displays initiated (simple regressions: Tank 2: df $=10 ; \mathrm{T}: t=$ 2.41, p < 0.05; 11-KT: $t=2.21, \mathrm{p}=0.052$ ) (Fig. 2). Male type did not influence the intercept or the slope of these regressions (Tank 2: $\mathrm{df}=8$, all p-values $>0.16$ ).

\section{Reproductive success}

All cod were identified in the pedigree analyses (Tables 2 \& 3). More genotyped eggs were spawned by wild than farmed females (LME model: $\mathrm{df}=30, t=4.58$, $\mathrm{p}<0.001$ ) (Fig. 3). Overall, wild males sired more eggs than farmed males ( $\mathrm{df}=29, t=3.74, \mathrm{p}<0.001$ ) (Fig. 3), but there was also a significant interaction between male and female type $(\mathrm{df}=30, t=3.31 ; \mathrm{p}<0.001)$. Wild males sired around $75 \%$ of the eggs released by wild females in both tanks, whereas the corresponding number for farmed females varied between 48 and $67 \%$ (Fig. 3).

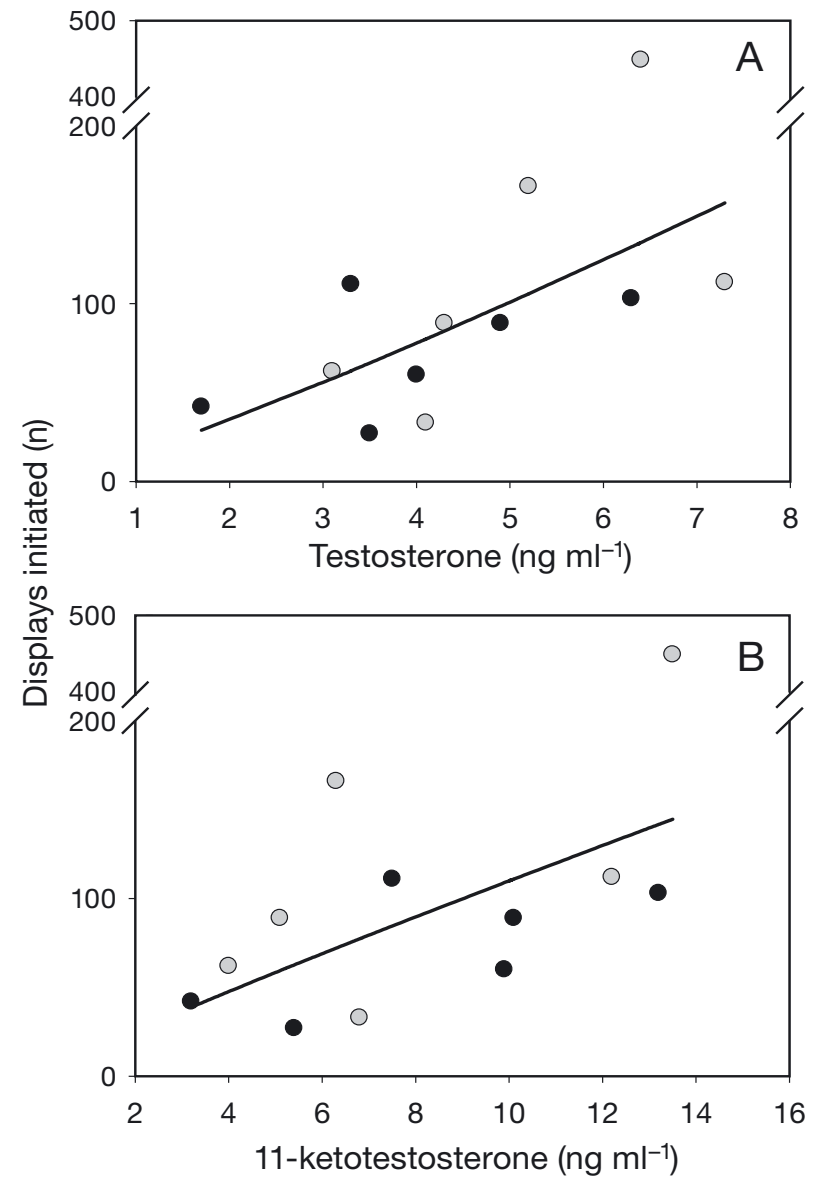

Fig. 2. Gadus morhua. Relationship between the number of displays initiated and (A) testosterone and (B) 11-ketotestosterone concentrations for wild $(\bullet)$ and farmed $(\bigcirc)$ males. Lines are the fitted regression lines 


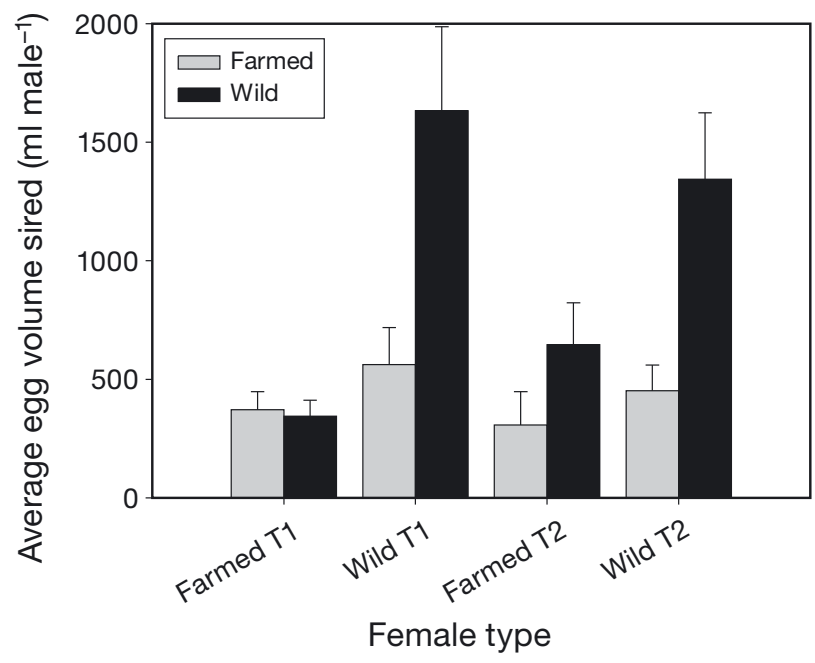

Fig. 3. Gadus morhua. Average male reproductive success given as the average volume of eggs fertilised by wild (black bar) and farmed (grey bar) males, in Tanks 1 (T1) and 2 (T2), separated into eggs spawned by farmed and wild females. Error bars: + SE

\section{Correlates of reproductive success}

No correlate of male reproductive success was found for either male type in Tank 1. In Tank 2 the relationship between displays initiated and reproductive success for wild males was strongly influenced by a single wild fish, which had a sired a relatively high proportion of eggs compared to the number of displays initiated. When we excluded this fish from the analyses there was a clear positive association for displays initiated and male reproductive success for wild males ( $\mathrm{df}=3, t=4.56, \mathrm{p}<0.05$ ) (Fig. 4). The interactive effect between MOT and female type also came out significant in Tank $2(\mathrm{df}=4, t=-3.98, \mathrm{p}<0.05)$, but this was

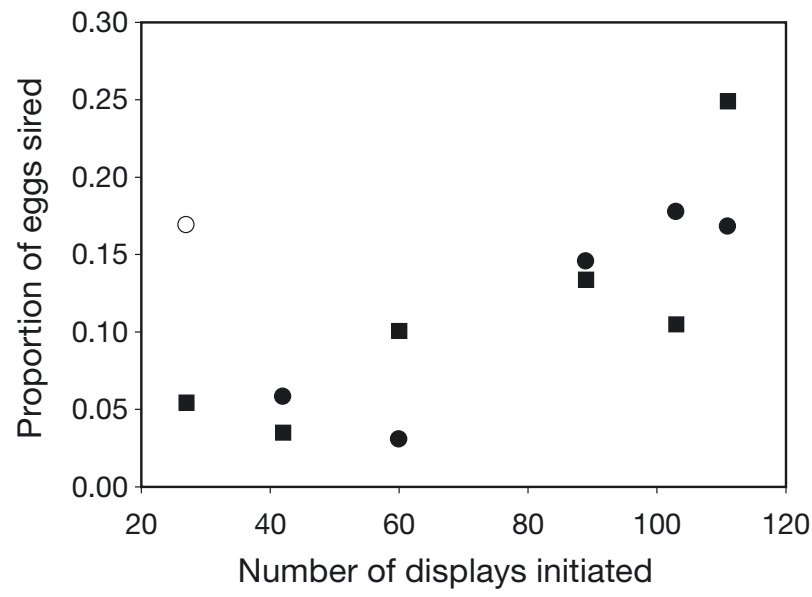

Fig. 4. Gadus morhua. Number of displays initiated by wild males and their relative reproductive success with wild (-) and farmed ( $\square$ ) females in Tank 2. The 'behavioural outlier' (O) is the fish that was excluded in the final analysis caused by a tendency for male MOT to be weakly positively correlated with reproductive success with farmed females and negatively correlated with reproductive success with wild females. Looking at the regression lines separately, neither relationship was significant $\left(\mathrm{r}^{2}=0.09, \mathrm{p}=0.55\right.$ and $\mathrm{r}^{2}=0.48, \mathrm{p}=0.13$ ) (data not shown). No other association between sperm traits and reproductive success was found in either tank.

\section{DISCUSSION}

Our results provide compelling evidence for the risk of hybridisation between fish that have spent their entire lives in captivity and their wild marine counterparts. We also shed light on the complexity of the cod mating system through examining reproductive success in relation to simultaneous measurements of morphology, physiology and sperm traits in addition to detailed analysis of behaviour.

\section{Reproductive behaviour of farmed and wild males and females}

This is, to our knowledge, the first study to investigate the outcome of mating competition between farmed and wild fish in a marine broadcast spawner. Earlier studies have primarily focused on salmonids that have a long history of domestication (see Huntingford 2004). Farmed male salmonids generally do poorly in spawning competition with wild males; they do not establish proper dominance hierarchies and they court females in bigger groups and fail to release sperm upon female egg release (Fleming et al. 1996, Weir et al. 2004). In contrast, the behaviour of farmed and wild male cod appeared similar in terms of the absolute numbers of reproductive behaviours initiated, the relative proportion of aggressions and courtships, whom they directed their displays towards and the duration of specific behaviours (Fig. 1). As we observed no spawnings where we could identify all individuals involved, we cannot comment on the possibility of differential sperm release by farmed and wild males.

The higher rates of courtships received by farmed females may either be linked to male preference or female behaviour. Although we cannot distinguish between these explanations, it is worth noting that in a recent field study the behaviour of wild females suggested that they avoided male spawning aggregations during the interval between spawning, whereas farmed females regularly visited the male aggregation (Meager et al. 2009, 2010).

Interestingly, males in the present study directed significantly more 'courtship' towards males than fe- 
males (Fig. 1). We suggest that males court fish in their immediate vicinity. Within our tanks males were mainly associated with the bottom, whereas females stayed closer to the surface (Meager et al. 2009). This situation is likely reciprocated in the field (Nordeide \& Folstad 2000, Meager et al. 2009). Male-male courtships in the Oreochromis mossambicus cichlid likely occur because of low sex discrimination by territorial fish (Oliveira \& Almada 1998). As aggression only occurred between males in the present study, male cod clearly can distinguish between the sexes. In hissing cockroach Gromphadorhina portentosa, a positive relationship between courtships directed at males and females in a male-male and male-female context, termed 'libido', was positively associated with reproductive success (Logue et al. 2009). This 'libido' syndrome coupled with sexual selection favouring high courtship intensity was suggested to explain the persistence of male-male courtships. Similar mechanisms may apply for cod. The generally longer duration of male-female courtships suggest that male recipients break off courtships faster than females or that initiator males are more persistent with a female recipient. Given the limited number of males in Tank 2, we encourage further studies on the reproductive behaviour of farmed and wild cod.

The positive association between steroid levels and the frequency of initiated displays is a new result for cod, but is commonly observed in other teleosts (Borg 1994, Rudolfsen et al. 2006). Folstad \& Karter (1992) suggested that increased hormonal levels suppress immune function, and the link to male displays may therefore function as an honest signal of male quality. This link has not been unequivocally demonstrated in fish, but indirect support for this theory exists (Kurtz et al. 2007).

\section{Reproductive success of farmed and wild cod and the risk of genetic introgression}

The present study demonstrates that both male and female farmed cod interbreed with their wild counterparts in mixed spawning shoals. Numerous hybridisations occurred in both tanks through both farmed sexes, although wild males had overall higher reproductive success than farmed males, and farmed females produced fewer offspring than wild females (Fig. 3). The latter result is likely caused by the commonly observed lower fertilisation success in farmed females ( $\varnothing$. Karlsen pers. obs.) and not a mismatch in the spawning period as farmed female offspring were identified throughout the study period in both tanks.

Whether or not hybridisation occurs in nature following a sea-pen escape depends on the ability of farmed cod to (1) navigate to spawning grounds and (2) enter the spawning shoal. While earlier studies have established (1) in a number of regions (e.g. Svåsand et al. 1990, Uglem et al. 2008), the results of a recent study suggest that farmed females but not farmed males enter spawning shoals (Meager et al. 2009, 2010). Field telemetry of the same putative population as we used in the present study indicated that farmed males were less likely to remain on the spawning ground, and those that did maintained positions above the spawning shoal (Meager et al. 2009, 2010).

Collectively, these results indicate that farmed females are the main vector for the introduction of farmed genes into wild populations, which is the same sexual bias in gene flow as found in salmon (Fleming et al. 1996, 2000, Weir et al. 2004). Nevertheless, the reproductive success of farmed males over the longer term is unclear, and we encourage further studies on other farmed and wild cod populations to test the generality of our results.

We have calculated reproductive success under the assumption that all fertilised eggs had equal probability of hatching. In reality, maternal and paternal effects may cause differential survival of early embryonic stages (e.g. Trippel et al. 2005). If, for example, crosses between farmed males and females consistently had lower survival pre-hatching than other type combinations, this could cause the patterns of reproductive success we observe, rather than behavioural mechanisms and female choice. We have no a priori reason to believe this is the case, but to test for this possibility it would be beneficial if future studies on reproductive interactions between farmed and wild cod estimate reproductive success both at the earliest egg stage possible and at later larval stages.

Interbreeding between artificially selected and wild organisms typically results in offspring with reduced fitness (Ellstrand 2003, Hails \& Morley 2005). For Atlantic salmon, reduced fitness in wild populations has been documented even at low levels of interbreeding (McGinnity et al. 2003). Even when using local broodstock, the genotype of farmed and wild fish rapidly diverges because of founder effects and genetic drift (Bekkevold et al. 2006). At the time of writing, >500 commercial cod-farming licenses have been issued in Norway, representing a total production capacity of $300000 \mathrm{t} \mathrm{yr}^{-1}$. In 2008, 304000 cod escapees were reported in Norway (Norwegian Directorate of Fisheries 2010). Interactions between farmed and wild stocks are expected to increase with continued expansion of the industry and with it the potential for negative impacts on the local coastal cod populations (Bekkevold et al. 2006, Jørstad et al. 2008, Uglem et al. 2008). The spawning stock biomass of the Norwegian Coastal cod population north of $62^{\circ} \mathrm{N}$ is estimated to be only $57000 \mathrm{t}$ in 2007 . The negative effects of inter- 
breeding and genetic introgression could thus be substantial in the near future. Maximum effort should therefore be focused on preventing escapes.

\section{The cod mating system}

Our results indicate a major element of female choice in the natural cod mating system. If male reproductive success was purely mediated through some male trait, like behaviour or sperm motility, we would expect the same patterns of male reproductive success regardless of female type. Instead, wild females reproduced principally with wild males, whereas farmed females spawned more or less equally with both male types (Fig. 3). This complexity concurs with previous studies (Hutchings et al. 1999, Rowe et al. 2007, 2008). In comparison, farmed and wild salmonids generally show wild male dominance, but the same patterns of reproductive success regardless of female origin (Fleming et al. 1996, Weir et al. 2004). As both male cod types behaved similarly, a plausible mechanism is that wild females rejected the farmed males based on their physical appearance, i.e. higher condition and their smaller pelvic fins (see Skjæraasen et al. 2008) or potentially, unrecorded cues such as pheromones, when choosing among the wild males based on their behaviour (Fig. 4). Whether the ultimate cause of this is phenotypic plasticity or genetic differences between farmed and wild fish is beyond the scope of the present study. Behaviour and fish size are the main determinants of reproductive success in wild cod populations (Rowe et al. 2008). The low size variation within our groups likely explains the lack of the latter association (see Bekkevold 2006). Age and spawning experience may also increase male reproductive success (Liley et al. 2002). Given that farmed fish grow faster and mature at earlier age than wild fish, it is not possible to match fish by size and age without introducing substantial biases, i.e. by starving farmed fish. Arguably, this could thus have relevance to our study. Nevertheless, repeat-spawning farmed males in Tank 2 did not do better than the recruit spawners in Tank 1 .

This is, to our knowledge, the first study to examine the power of sperm traits as explanatory variables of male reproductive success in a freely breeding teleost. Using sperm collected from the males in Tanks 1 and 2 we earlier found that the main determinant of in vitro sperm competition was VCL in seawater, which positively correlated to male reproductive success (Skjæraasen et al. 2009). The same has been found in domestic fowl Gallus gallus (Birkhead et al. 1999) as well as other externally fertilising species (Gage et al. 2004, Casselman et al. 2006). In the present study, sperm traits were not associated with reproductive success.
This does not mean that sperm competition is absent given the frequently observed multiple paternity in single batches (e.g. Bekkevold et al. 2002 and the present study). Sperm traits may also change during the spawning season (Rakitin et al. 1999) and can be modified with female presence (Gasparini et al. 2009). Factors like ejaculate volume, although impossible to measure in freely spawning fish, are likely also important. Nevertheless, while numerous studies have inferred the importance of sperm traits from in vitro competition only, ours is the first to assess the importance of sperm traits for reproductive success in freely spawning fish. In agreement with the distinct reproductive behaviours observed in cod spawning groups (Brawn 1961a, Hutchings et al. 1999), overall male reproductive success was not associated with sperm motility.

\section{Concluding remarks}

The present study simulates the very real scenario of male and female escapee cod entering a natural spawning ground (Svåsand et al. 1990). In this context, we showed that both male and female farmed cod are likely to hybridise with wild fish. Together with the results from earlier field work (Meager et al. 2009, 2010), the present results indicated that introgression of farmed genes into wild gene pools is likely, particularly from farmed females. Even so, gene flow is not the only risk imposed by farmed fish to wild stocks (Bekkevold et al. 2006). In fishes with complex mating systems such as cod, influx of large numbers of escapees on spawning grounds may interfere with the natural mating system. The propensity of wild males to court farmed over wild females indicates that this is a salient risk. The ecological and genetic consequences of farmed fish in marine environments should be a priority for future work.

Acknowledgements. The study was approved by the Norwegian Council for Animal Research. We thank the staff at Austevoll research station for help with husbandry and sampling of fish. J. Titelman kindly provided comments to drafts of the manuscript. The study was funded by the Norwegian Research Council project nos. 172649/S40 and 177744/V40.

\section{LITERATURE CITED}

Araki H, Cooper B, Blouin MS (2007) Genetic effects of captive breeding cause a rapid, cumulative fitness decline in the wild. Science 318:100-103

Bekkevold D (2006) Male size composition affects male reproductive variance in Atlantic cod Gadus morhua L. spawning aggregations. J Fish Biol 69:945-950

Bekkevold D, Hansen MM, Loeschcke V (2002) Male reproductive competition in spawning aggregations of cod (Gadus morhua, L.). Mol Ecol 11:91-102 
Bekkevold D, Hansen MM, Nielsen EE (2006) Genetic impact of gadoid culture on wild fish populations: predictions, lessons from salmonids, and possibilities for minimizing adverse effects. ICES J Mar Sci 63:198-208

Birkhead TR, Møller AP (1998) Sperm competition and sexual selection. Academic Press, San Diego, CA

Birkhead TR, Martinez JG, Burke T, Froman DP (1999) Sperm mobility determines the outcome of sperm competition in the domestic fowl. Proc R Soc Lond B 266:1759-1764

Borg B (1994) Androgens in teleost fishes. Comp Biochem Physiol C 109:219-245

Born AF, Immink AJ, Bartley DM (2004) Marine and coastal stocking: global status and information needs. In: Bartley B, Leber KM (eds) Marine ranching. FAO Fish Tech Pap 429: 1-18

Brawn VM (1961a) Reproductive behaviour of the cod (Gadus callarias L.). Behaviour 18:177-198

Brawn VM (1961b) Sound production by the cod (Gadus callarias L.). Behaviour 18:177-198

Brooker AL, Cook D, Bentzen P, Wright JM, Doyle RW (1994) Organization of microsatellites differs between mammals and cold-water teleost fish. Can J Fish Aquat Sci 51: 1959-1966

Brown C, Laland K (2001) Social learning and life skills training for hatchery reared fish. J Fish Biol 59:471-493

Casselman SJ, Schulte-Hostedde AI, Montgomerie R (2006) Sperm quality influences male fertilization success in walleye (Sander vitreus). Can J Fish Aquat Sci 63:2119-2125

> Dahle R, Taranger GL, Karlsen Ø, Kjesbu OS, Norberg B (2003) Gonadal development and associated changes in liver size and sexual steroids during the reproductive cycle of captive male and female Atlantic cod (Gadus morhua L.). Comp Biochem Physiol A 136:641-653

> Darwish TL, Hutchings JA (2009) Genetic variability in reaction norms between farmed and wild backcrosses of Atlantic salmon (Salmo salar). Can J Fish Aquat Sci 66: 83-90

Ellstrand NS (2003) Dangerous liaisons? When cultivated plants mate with their wild relatives. Johns Hopkins University Press, Baltimore, MD

> Fleming IA, Jonsson B, Gross MR, Lamberg A (1996) An experimental study of the reproductive behaviour and success of farmed and wild Atlantic salmon (Salmo salar). J Appl Ecol 33:893-905

> Fleming IA, Hindar K, Mjolnerod IB, Jonsson B, Balstad T, Lamberg A (2000) Lifetime success and interactions of farm salmon invading a native population. Proc R Soc Lond B 267:1517-1523

Folstad I, Karter AJ (1992) Parasites, bright males, and the immunocompetence handicap. Am Nat 139:603-622

Gage MJG, Macfarlane CP, Yeates S, Ward RG, Searle JB, Parker GA (2004) Spermatozoal traits and sperm competition in Atlantic salmon: relative sperm velocity is the primary determinant of fertilization success. Curr Biol 14: 44-47

Gasparini C, Peretti AV, Pilastro A (2009) Female presence influences sperm velocity in the guppy. Biol Lett 5:792-794

Hails RS, Morley K (2005) Genes invading new populations: a risk assessment perspective. Trends Ecol Evol 20:245-252

Höglund J, Alatalo RV (1996) Leks. Princeton University Press, Princeton, NJ

$>$ Huntingford FA (2004) Implications of domestication and rearing conditions for the behaviour of cultivated fishes. J Fish Biol 65:122-142

Hutchings JA, Baum JK (2005) Measuring marine fish biodiversity: temporal changes in abundance, life history and demography. Philos Trans R Soc B 360:315-338
Hutchings JA, Bishop TD, McGregor-Shaw CR (1999) Spawning behaviour of Atlantic cod, Gadus morhua: evidence of mate competition and mate choice in a broadcast spawner. Can J Fish Aquat Sci 56:97-104

Jonsson B, Jonsson N (2006) Cultured Atlantic salmon in nature: a review of their ecology and interaction with wild fish. ICES J Mar Sci 63:1162-1181

Jørstad KE, Van Der Meeren T, Paulsen OI, Thomsen T, Thorsen A, Svåsand T (2008) 'Escapes' of eggs from farmed cod spawning in net pens: recruitment to wild stocks. Rev Fish Sci 16:285-295

Karlsen Ø, Holm JC (1994) Ultrasonography, a noninvasive method for sex determination in cod (Gadus morhua). J Fish Biol 44:965-971

Kirkpatrick M, Ryan MJ (1991) The evolution of mating preferences and the paradox of the lek. Nature 350:33-38

Kjesbu OS (1989) The spawning activity of cod, Gadus morhua L. J Fish Biol 34:195-206

Kjesbu OS, Taranger GL, Trippel EA (2006) Gadoid mariculture: development and future challenges: introduction. ICES J Mar Sci 63:187-191

> Kurtz J, Kalbe M, Langefors S, Mayer I, Milinski M, Hasselquist D (2007) An experimental test of the immunocompetence handicap hypothesis in a teleost fish: 11-ketotestosterone suppresses innate immunity in three-spined sticklebacks. Am Nat 170:509-519

> Liley NR, Tamkee P, Tsai R, Hoysak DJ (2002) Fertilization dynamics in rainbow trout (Oncorhynchus mykiss): effect of male age, social experience, and sperm concentration and motility on in vitro fertilization. Can J Fish Aquat Sci 59:144-152

> Logue DM, Mishra S, McCaffrey D, Ball D, Cade WH (2009) A behavioral syndrome linking courtship behavior toward males and females predicts reproductive success from a single mating in the hissing cockroach, Gromphadorhina portentosa. Behav Ecol 20:781-788

- McGinnity P, Prodohl P, Ferguson K, Hynes R and others (2003) Fitness reduction and potential extinction of wild populations of Atlantic salmon, Salmo salar, as a result of interactions with escaped farm salmon. Proc Biol Sci 270: 2443-2450

McKaye KR (1983) Ecology and breeding behavior of a cichlid fish, Cyrtocara eucinostomus, on a large lek in Lake Malawi, Africa. Environ Biol Fishes 8:81-96

> Meager JJ, Skjæraasen JE, Fernö A, Karlsen Ø, Løkkeborg S, Michalsen K, Utskot SO (2009) Vertical dynamics and reproductive behaviour of farmed and wild cod Gadus morhua. Mar Ecol Prog Ser 389:233-243

Meager JJ, Skjæraasen JE, Fernö A, Løkkeborg S (2010) Reproductive interactions between fugitive farmed and wild cod (Gadus morhua) in the field. Can J Fish Aquat Sci

> Miller KM, Le KD, Beacham TD (2000) Development of triand tetranucleotide repeat microsatellite in Atlantic cod (Gadus morhua). Mol Ecol 9:238-239

> Moe H, Dempster T, Sunde LM, Winther U, Fredheim A (2007) Technological solutions and operational measures to prevent escapes of Atlantic cod (Gadus morhua) from sea cages. Aquac Res 38:91-99

Naylor R, Hindar K, Fleming IA, Goldburg R and others (2005) Fugitive salmon: assessing the risks of escaped fish from net-pen aquaculture. Bioscience 55:427-437

Neff BD, Pitcher TE (2008) Mate choice for non-additive genetic benefits: a resolution to the lek paradox. $\mathrm{J}$ Theor Biol 254:147-155

Nilsson J (2004) Acoustic behaviour of spawning cod (Gadus morhua L). Candidatus scientiarum thesis. University of Bergen, Bergen 
Nordeide JT, Folstad I (2000) Is cod lekking or a promiscuous group spawner? Fish Fish 1:90-93

Norwegian Directorate of Fisheries (2010) Statistics for Aquaculture (online). Available from www.fiskeridir.no/fiskeridir/ statistikk/akvakultur/roemmingsstatistikk (accessed 23 July 2010; in Norwegian)

Oliveira RF, Almada VC (1998) Mating tactics and male-male courtship in the lek-breeding cichlid Oreochromis mossambicus. J Fish Biol 52:1115-1129

Olsen EM, Knutsen H, Gjosaeter J, Jorde PE, Knutsen JA, Stenseth NC (2008) Small-scale biocomplexity in coastal Atlantic cod supporting a Darwinian perspective on fisheries management. Evol Appl 1:524-533

O'Reilly PT, Canino MF, Bailey KM, Bentzen P (2000) Isolation of twenty low stutter di- and tetranucleotide microsatellites for population analyses of walleye Pollock and other gadoids. J Fish Biol 56:1074-1086

Pauly D, Christensen V, Guenette S, Pitcher TJ and others (2002) Towards sustainability in world fisheries. Nature 418:689-695

R Development Core Team (2009) R: a language and environment for statistical computing. R Foundation for Statistical Computing, Vienna. http://www.r-project.org/

Rakitin A, Ferguson MM, Trippel EA (1999) Spermatocrit and spermatozoa density in Atlantic cod (Gadus morhua): correlation and variation during the spawning season. Aquaculture 170:349-358

Rowe S, Hutchings JA (2006) Sound production by Atlantic cod during spawning. Trans Am Fish Soc 135:529-538

Rowe S, Hutchings JA, Skjæraasen JE (2007) Nonrandom mating in a broadcast spawner: mate size influences reproductive success in Atlantic cod (Gadus morhua). Can J Fish Aquat Sci 64:219-226

Rowe S, Hutchings JA, Skjæraasen JE, Bezanson L (2008) Morphological and behavioural correlates of reproductive success in Atlantic cod Gadus morhua. Mar Ecol Prog Ser 354:257-265

Rudolfsen G, Figenschou L, Folstad I, Nordeide JT, Soreng E (2005) Potential fitness benefits from mate selection in the Atlantic cod (Gadus morhua). J Evol Biol 18:172-179

Rudolfsen G, Figenschou L, Folstad I, Tveiten H, Figenschou M (2006) Rapid adjustments of sperm characteristics in relation to social status. Proc Biol Sci 273:325-332

Editorial responsibility: Hans Heinrich Janssen, Oldendorf/Luhe, Germany
Sarvas TH, Fevolden SE (2005) The scnDNA locus Pan I reveals concurrent presence of different populations of Atlantic cod (Gadus morhua L.) within a single fjord. Fish Res 76:307-316

- Schulz R (1985) Measurement of five androgens in the blood of immature and maturing rainbow trout, Salmo gairdneri (Richardson). Steroids 46:717-726

Skjæraasen JE, Rowe S, Hutchings JA (2006) Sexual dimorphism in pelvic fin length of Atlantic cod. Can J Zool 84: $865-870$

Skjæraasen JE, Meager JJ, Karlsen Ø (2008) The expression of secondary sexual characteristics in recruit- and repeatspawning farmed and wild Atlantic cod (Gadus morhua). ICES J Mar Sci 65:1710-1716

Skjæraasen JE, Mayer I, Meager JJ, Rudolfsen G, Karlsen Ø, Haugland T, Kleven O (2009) Sperm characteristics and competitive ability in farmed and wild cod. Mar Ecol Prog Ser 375:219-228

Svåsand T, Jørstad KE, Kristiansen TS (1990) Enhancement studies of coastal cod in western Norway. Part I. Recruitment of wild and reared cod to a local spawning stock. J Cons Int Explor Mer 47:5-12

> Taggart JB (2007) FAP: an exclusion-based parental assignment program with enhanced predictive functions. Mol Ecol Notes 7:412-415

Trippel EA, Kraus G, Koster FW (2005) Maternal and paternal influences on early life history traits and processes of Baltic cod Gadus morhua. Mar Ecol Prog Ser 303:259-267

Uglem I, Bjorn PA, Dale T, Kerwath S and others (2008) Movements and spatiotemporal distribution of escaped farmed and local wild Atlantic cod (Gadus morhua L.). Aquac Res 39:158-170

Ward RD (2006) The importance of identifying spatial population structure in restocking and stock enhancement programmes. Fish Res 80:9-18

> Weir LK, Hutchings JA, Fleming IA, Einum S (2004) Dominance relationships and behavioural correlates of individual spawning success in farmed and wild male Atlantic salmon, Salmo salar. J Anim Ecol 73:1069-1079

Wesmajervi MS, Tafese T, Stenvik J, Fjalestad KT, Damsgård B, Delghandi M (2007) Eight new microsatellite markers in Atlantic cod (Gadus morhua L.) derived from an enriched genomic library. Mol Ecol Notes 7:138-140

Submitted: October 10, 2009 Accepted: May 25, 2010

Proofs received from author(s): July 24, 2010 